\title{
Ending the sexist blame game
}

$\mathrm{M}$ ore often than not, questions of access to health care rest on the availability of health care professionals. In recent weeks, our colleagues and medical students have expressed deep concern about media reports that suggest the physician shortage in Canada is rooted, at least partially, in the fact that women are now more equitably represented within the profession.

National media coverage of the 2007 National Physician Survey, a joint initiative of the Canadian Medical Association, The Royal College of Physicians and Surgeons of Canada and the College of Family Physicians of Canada, focused heavily on the growth in the number of female physicians and the claim that they work fewer hours compared with their older male colleagues. An example of a typical headline is "Doctors plan to quit or cut hours: More than half the number of new physicians under 35 are women" (Nanaimo Daily News). The most egregious example of this emerging perspective came in the Jan. 2, 2008, cover story in Maclean's, headlined "Adding fuel to the doctor crisis." The message conveyed by much of the coverage and commentary implied that female physicians simply do not work as hard as their male colleagues. These reports seem to be telling Canadians "if you're having trouble finding a physician, a large part of the blame lies with the increasing number of female doctors in the system."

It is disheartening in the 2Ist century to see women as scapegoats for the broader failings of our health care system. Health human resource planning is an extremely complex and multidimensional area of policy formulation. The primary cause of our current physician shortage is myopic health planning. Medical school enrolment was cut in the early I990s, at a time when the population was growing and the large "boomer" demographic (notably including aging physicians) was reaching the age when more medical care is often required. Limiting medical school enrolment was a colossal miscalculation. We are currently reaping what was sown by our policy-makers more than a decade ago.

In Canada, $33.3 \%$ of physicians are female; $48.6 \%$ of physicians under age 40 are women. ${ }^{1}$ Women provide more services than men in certain areas of medicine. ${ }^{2}$ The decline in physicians' working hours is attributed more to the decline in hours worked by male physicians than the increasing proportion of female physicians. ${ }^{3}$ Women do work differently than their male counterparts: they put in many more hours in combining professional duties, childcare and household responsibilities. ${ }^{4}$

All doctors have a reasonable expectation of family life outside of work. A reasonable health human resources strategy should accept that reality. Preventing burnout and keep- ing our health care workforce active and motivated are crucial. Paying attention to personal and family responsibilities is a good thing for male and female doctors, their families and ultimately their patients.

From Romanow and Kirby to McKendry and the George expert panel, we are all attempting to understand and address this serious issue for all Canadians. To suggest that a physician workforce that more equitably represents women in the workplace is the barrier to access is frankly a sexist excuse for logic. To disparage in any way the intelligent, dedicated women from Canada and elsewhere who have chosen to devote their lives to medical practice is shameful.

The blame game gets us no closer to achieving what Canadians expect from us - a health care system that provides quality and timely access to well-trained, well-equipped, compassionate health care providers.

\section{Carol Herbert MD}

Dean

Schulich School of Medicine and Dentistry

University of Western Ontario

London, Ont.

\section{Catharine Whiteside MD PhD}

Dean

Faculty of Medicine

David McKnight MD MHSc

Associate Dean

Equity and Professionalism

Sarita Verma LLB MD

Vice-Dean

Postgraduate Medical Education

Lynn Wilson MD

Chair

Family and Community Medicine

University of Toronto

Toronto, Ont.

With the Editorial-Writing Team (Paul C. Hébert MD MHSc, Matthew B. Stanbrook MD PhD, Barbara Sibbald BJ, Ken Flegel MDCM MSc, Noni MacDonald MD MSc and Amir Attaran LLB DPhil)

\section{REFERENCES}

I. Canadian Institute for Health Information. Supply, distribution and migration of Canadian physicians, 2006. Ottawa: The Institute; 2007. p. 4.

2. Tepper J. The evolving role of Canada's family physicians. Ottawa: Canadian Institute for Health Information; 2004. Available: http://secure.cihi.ca/cihiweb/products /PhysiciansREPORT_eng.pdf (accessed 2008 Feb 6).

3. Jeon SH, Hurley J. The relationship between physician hours of work, service volume and service intensity. Can Public Policy 2007;33(Suppl I):17-30.

4. Average hours spent per week by activity \& sex. Available: www.cma.ca/multimedia ICMA/Content_Images/Inside_cma/Statistics/pwr-average6.pdf(accessed 2008 Feb 6). 